INTERNATIONAL ENVIRONMENTAL LAW

DOI: https://doi.org/10.24833/0869-0049-2021-4-21-39

Research article Received 22 May 2021

\title{
Senko PLICANIC
}

Faculty of Law, University of Ljubljana,

2, Poljanski nasip, Ljubljana, Slovenia, Si-1000

senko.plicanic@pf.uni-lj.si

ORCID: 0000-0002-0386-3595

\section{HOW TO OVERCOME IMPOTENCE OF ENVIRONMENTAL LAW \\ IN THE AGE OF ANTHROPOCENE: FOUNDATIONS OF ECOCENTRIC LAW}

INTRODUCTION. This scientific article discusses the reaosns for inefficiency ("impotence") of modern environmental law as a normative reaction to the "destruction of Nature". The scope of the destruction of Nature has been broadening. The environmental protection law has thus not influenced the resurrection of "destroyed Nature".

MATERIALS AND METHODS. Consistent with explanatory and theory-building research, the methods used are those of historical legal research as well as general scientific methods, such as analysis, synthesis, analogy, description, and deduction.

RESEARCH RESULTS. The essential reasons for the current excessiveness (intemperance) of man's interaction with Nature (the reasons for the "destruction of Nature") and/or reasons for the inefficiency of the modern environmental law should be sought for in the dominant anthropocentric cultural paradigm of the western cultures oriented towards an un-limited material progress. If anthropocentrism (exploitativeness) as the basis of human utilitarian interaction with nature has led to the "destruction of nature," there is no doubt that the ecological reason remaining within the anthropocentric construction of Nature can not lead to its "resurrection". Only the setting-up of the ecocentric construction of Nature may lead to the "resurrection" of Nature. This orientation must be followed by the nomos of the western cultures. A new law of nature on the basis of the new, ecocentric ontology and ethics is therefore necessary.

DISCUSSION AND CONCLUSIONS. In this article, the basics of a new ecocentric legal philospohy as the foundation of modern environmental law have been proposed. The scientific realisation of man's equality in the network of co-dependent natural entities in the last decades shows man his initial position - that is his (equal) postition in Nature. The determination of the rules of conduct which man must respect in interaction with Nature implies an expansion of the idea of law itself (justice and correctness) towards the interaction between man and Nature and not only the interaction within human community. Consequently, the economic interaction has to be maintained within the framework ensuring the vitality of other biotic communities. Also, incorporation of Nature in the very essence of law inevitably triggers a redefinition of legal values. The natural equilibrium, i.e., the equilibrium of life (including human life) becoming a legal value, we could speak of the expansion of the legal subject, i.e. the expansion of values which are the subject of legal protection. The initial position of the natural equilibrium addresses the issue of relationship of the new legal value towards the existing fundamental legal values of the western cultures. The enforcement of the maintenance of natural equilibrium may also demand a limitation of another legally protected value, for example, 
the right to the freedom of movement or some other human right. The new value, i.e., the maintenance of natural equilibrium, must be incorporated in the "contracts of statehood", that is in the constitutions of the western countries as one of main legal values, next to "freedom", "democracy" and "private property". The entry of Nature in the western (legal) value system is a conditio sine qua non for an efficient change in the legal order and, most importantly, for a change in man's attitude towards Nature in everyday's life.

KEYWORDS: inefficiency of modern environmental law, anthropocentrism, ecocentrism, expansion of the idea of law, ecocentric legal philosophy, redefinition of legal values, natural equilibrium as a basic and common legal value

FOR CITATION: Plicanic S. How to Overcome Impotence of Environmental Law in the Age of Anthropocene: Foundations of Ecocentric Law. - Moscow Journal of International Law. 2021. No.4. P. 21-39. DOI: https://doi.org/10.24833/0869-0049-2021-421-39

The author declares the absence of conflict of interest.

\section{МЕЖДУНАРОДНОЕ ПРАВО И ОКРУЖАЮЩАЯ СРЕДА}

DOI: https://doi.org/10.24833/0869-0049-2021-4-21-39

Исследовательская статья Поступила в редакцию: 22.05.2021 Принята к публикации: 01.11.2021

\section{Сенко ПЛИЧАНИЧ}

Факультет права, Университет Любляны, Полянская насыпь, д. 2, Любляна, Si-1000, Словения senko.plicanic@pf.uni-lj.si ORCID: 0000-0002-0386-3595

\section{КАК ПРЕОДОЛЕТЬ БЕССИЛИЕ ЭКОЛОГИЧЕСКОГО ПРАВА В ЭПОХУ АНТРОПОЦЕНА: ОСНОВЫ ЭКОЦЕНТРИЧНОГО ПРАВА}

\begin{abstract}
ВВЕДЕНИЕ. Данная научная статья посвящена причинам неэфбективности («бессилия») современного экологчческого права как ответа нормативной системы на «уничтожение Природы»». Маситабы разрушения природной среды увеличиваются. Следовательно, право охраны окружающей среды не смогло привести к возрождению «уничтоженной Природы»».
\end{abstract}

МАТЕРИАЛЫ И МЕТОДЫ. В соответствии с принцииами объяснительных и теоретических исследований, автор статьи применял исторический метод юридической науки, а также такие общенаучные методы познания, как анализ, синтез, аналогия, описание и дедукиия.

РЕЗУЛЬТАТЫ ИССЛЕДОВАНИЯ. СуществеНные причины чрезмерности (неумеренности) во взаимодействии человека и природы (причины «уничтожения Природыь») и/или причины неэфбфективности современного экологического права следует искать в преобладающей антропоцентричной культурной парадигме западных стран, ориентированных на безграничный материальный прогресс. Поскольку антропоцентризм (эксплуататорское мыциление) как основа человеческого 
утилитаристского взаимодействия с окружающей средой привел к «уничтожению Природьљ», не вызывает сомнений, что экологическое мьиление в рамках антропоиентричной трактовки Природы не может привести кее «возрождению». Только принятие экоцентричной трактовки Природь может привести кее «возрождению». Западные государства должны следовать этому направлению в своем законодательстве. Таким образом, необходимо новое право охраны природь, основанное на новой, экочентричной онтологической и этической билософии.

ОБСУЖДЕНИЕ И ВЫВОДЫ. В настоящей статье выљвинуты начала новой экочентричной философии права как основы современного экологического права. Научные формы реализации равенства индивидов в системе созависимьх природньх образований в последние десятилетия позволяют выявить исходное положение человека в мире - то есть, (равное) по отношению к Природе. Определение правил поведения, которьм должен следовать человек в своем взаимодействии с Природой, подразумевает распространение идеи права как таковой (справедливости и правильности) на взаимодействие между человеком и природой, а не только на взаимодействие людей в обществе. Следовательно, экономическая деятельность должна осуществляться в правовых рамках, обеспечиваюших жизнеспособность иных природных общностей. Также включение Природь в концепцию права неизбенно влечет за собой пересмотр правовых иенностей общества. Поскольку природньй баланс, то есть баланс жизни (в том числе, человеческой) становится правовой ценностью, можно говорить о расширении предмета правового регулирования, то есть расширения круга ценностей, которье

\section{Introduction}

$\mathrm{T}$ The purpose of this article is to analyze the reasons for the ineffectiveness of modern environmental law and on this basis to propose the legal and philosophical foundations of the new environmental law. The essential reasons for the current excessiveness (intemperance) of man's interaction with Nature (the reasons for the "destruction of Nature") and/or reasons for the inefficiency of the modern environmental law should be sought for in the dominant anthropocentric cultural paradigm of the western cultures oriented towards an подлежат правовой зашите. Постановка вопроса о природном балансе затрагивает проблему соотношения новой правовой ценности и существующих базовых правовых иеннностей западных стран. Правовая защита природного баланса может также потребовать ограничения иных защищаемыхх правом ценностей, например, права на свободу передвинения или каких-либо иных прав человека. Положения о новой ценности - поддержании природного баланса - должны быть включены в «общественные договоры о государственности», то есть в конституици западных государств как одна из главных правовых иеннностей наряду со «свободой», «демократией» и «частной собственностью». Включение Природы в западную систему (правовых) иенностей является conditio sine qua поп действительного изменения правопорядка и, что наиболее важно, отночения человека к Природе в его повседневной жизни.

КЛЮЧЕВЫЕ СЛОВА: неэффективность современного экологического права, антропоцентризм, экоцентризм, распространение концепции права, экоцентричная философия права, пересмотр правовых ценностей, природный баланс как базовая и общая правовая ценность

ДЛЯ ЦИТИРОВАНИЯ: Пличанич С. Как преодолеть бессилие экологического права в эпоху антропоцена: основы экоцентричного права. - Московский журнал международного права. 2021. №. 4. C. 21-39. DOI: https://doi.org/10.24833/0869-00492021-4-21-39

Автор заявляет об отсутствии конфликта интересов.

unlimited material progress. This article thus analyzes the foundations of new ecocentric legal philospohy. This approach is original at the global level and is important at both the theoretical and applied levels. The new ecocentric legal philosophy should become the foundation of modern environmental law

\section{2. "Impotence" of the modern environmental protection law}

In the past decades the awareness of the necessity to "legislate temperance" [Hardin 1968] in hu- 
man (economic) interaction ${ }^{1}$ with Nature has been heightened. The inefficiency and/or "impotence" [Eder 1996] of the normative reaction to the "destruction of Nature" [Merchant 1980], i.e., the development of the environmental law in the second half of the 20th century is becoming increasingly evident. The scope of the destruction of Nature has been broadening. The environmental protection law has thus not influenced the resurrection of "destroyed Nature" [Ponting 1993].

Thanks to the scientific findings in the last few centuries concerning man's co-dependent and equivalent centrality in the "cosmic network" of biotic natural entities ${ }^{2}$, the main levers which have brought about the destruction of Nature and are at the same time the main reasons for the inefficiency and/or "impotence" of the environmental protection law have become increasingly prominent.
The essential reasons for the current excessiveness (intemperance) of man's interaction with $\mathrm{Na}$ ture (the reasons for the "destruction of Nature") and/or reasons for the inefficiency of the current normative interference (i.e., the environmental protection law) should be sought for in the dominant anthropocentric cultural paradigm ${ }^{3}$ of the western cultures oriented towards an un-limited material progress in the age of Antrhopocene [Charting...2019:3-4] .

The morality "controlling" man's interaction with Nature has remained unchanged, i.e., utilitarian ${ }^{5}$. The "ecological reason" stems from the belief that man's exploitation of nature has gone too far and hence is in favour of limitation and prevention of nature pollution and of a more rational exploitation of nature. The implementation of the ecological reason leads therefore to a more rational exploitation; however,

\footnotetext{
1 The direct subject of the law is the interaction between man and Nature. The interaction is twofold: spiritual, on the one hand, and material, on the other hand, (the use of Nature and waste disposal). Within the latter, economic interaction is specially important. Economic interaction is instigated by the desire to meet man's needs, whilst from the point of view of Nature and/or natural equilibrium it burdens the environment. It covers utilitarian interaction (to meet man's needs, in particular, energy needs) and waste disposal (in the broader sense) and nowadays (mostly industrial waste), i.e., pollution.

2 The findings of quantum physics (W.Heisenberg, N. Bohr, G. Chew et al.) and other nature sciences (H. Maturana, F. Varela et al.) reveal the co-dependence and equi-valence of all natural entities including man. We should call the reader's attention to the knowledge which for millennia has been accessible to other cultures (Australia's "aborigines," the North-American Indians). At the same time, this knowledge could be traced back to the very threshold of the western cultures to the time before Socrates. The western civilisation needed two thousand and five hundred years to acquire the knowledge which other cultures have had since the beginning. The path to this knowledge has been paved with the destruction of Nature and the destruction of most of these "primitive" cultures. The West is increasingly aware that the tradition of these "primitive" cultures which it has been destroying with such thoroughness contains human knowledge amassed through millennia (according to the latest anthropological and archaeological research, the history of Australia's "aborigines" has continued uninterrupted for 80,000 years - Dreamtime) of the norms of human behaviour, ensuring harmony between human needs and Nature, to which man also belongs. It is a well-known fact that one of the key characteristics of the non-European "non-civilised" cultures (one of the fundamental criteria of civilisation was the scope of "cultivation" (exploitation) of Nature) has been environmental sensibility. This knowledge must, therefore, be incorporated in human culture. To paraphrase Bacon, knowledge is power, but not the power to destroy and to dominate Nature, but power to re-introduce harmony (equilibrium) with Nature.

3 The expression "paradigm" originates in the ancient Greek ("paradeigma") and means a "model", "pattern". The notion of "paradigm" should be understood in this essay as a combination of beliefs, perceptions and values which form a certain conception of reality in science, philosophy, and in society and/or culture in general. For more detail on scientific paradigms see [Kuhn 1962].

4 "The Anthropocene is characterised by a state change in the Earth system. The Earth system encompasses the interconnected natural cycles and interacting biophysical and chemical processes of our planet. The state change observed in the onset of the Anthropocene refers to the disruptions to the Earth system which have moved the planet's physical, biological and chemical systems beyond the stable functioning observed in the Holocene. The Holocene began approximately 11,700 years ago and provided the conditions for human societies to flourish. It is the geological time period that preceded the Anthropocene. The Holocene encompassed most of the history of humanity and was characterised by rapid growth of human populations across the planet. The stable functioning of Earth's life support systems, characteristic of the Holocene, are being increasingly disrupted. Though human influence of the Earth system has occurred over centuries, it is only recently that anthropogenic activities have had a significant impact on the structure and function of this system. The expression 'Anthropocene' was first proposed at the start of the new millennium. Despite its conceptual foundations in geology, it has come to encompass a range of geological, ecological, sociological and anthropological changes in the Earth's recent history. References to the Anthropocene are increasingly found across a range of disciplines. The term has come to encapsulate the unprecedented planetary-scale changes caused by anthropogenic activity) and the novel challenges and opportunities which come about from appreciation of these changes; and the new thinking required to successfully navigate global environmental change" [Charting ...2019:3-4].

5 The use value of Nature is therefore quintessential: "Nature is perceived and experienced as an object of human needs" [Eder 1996:VII].
} 
man's interaction with Nature continues to remain destructive (exploitative).

The spiritual background of environmental protection law is comparable to the spiritual background of the first legal norms which limited industrial pollution (before the "environmental explosion" of the '60s) $)^{6}$. The spiritual background of both is anthropocentric - there is no shift in the comprehension of Nature which continues to be understood instrumentally, i.e., as "environment" for the use of man and has to be kept clean or in some other way befitting man's comfort and health [Tarlock 1988:34; Eder 1996:123; Ortolano 1997:65, Dryzek 1997:75; Charting ...2019:1-3; Kotzé 2019:2-6].

"Ecological rationality" which has encouraged the formation of the environmental law has preserved its anthropocentric nature. The thelos of the environmental law is not the transformation of unlimitedness (exploitativeness) of the utilitarian (and in general burdensome) interaction with nature, but merely the formation of "safety mechanisms" for the purpose of the protection of human health and comfort.

In terms of such premises, the "impotence" of the environmental law is logical, i.e., no improvement is noticeable in the "environment;" on the contrary, the scope of the destruction of Nature is broadening.

If anthropocentrism (exploitativeness) as the basis of human utilitarian interaction with nature has led to the "destruction of nature," there is no doubt that the ecological reason remaining within the anthropocentric construction of Nature can not lead to its "resurrection". Only the setting-up of the ecocentric construction of Nature may lead to the "resurrection" of Nature ${ }^{8}$.

This orientation must be followed by the nomos ${ }^{9}$ of the western cultures. A new law of nature on the basis of the new, ecocentric ontology and ethics is therefore necessary ${ }^{10}$.

\section{From the anthropocentric to the ecocentric (philosophical) construction of Nature - creation of a new (ecocentric) "philosophy of nature"}

In the last decades, the issue of a redefinition of the relationship between man and Nature has become an increasingly important philosophical issue also within the western philosophy which has throughout its history been predominantly anthropocentric (and anthropomorphic) ${ }^{11}$.

A "new philosophy of nature"12 incorporating the ecological awareness ${ }^{13}$ is arising also from the western philosophical tradition, i.e., from the pre-Socratic philosophy [Philosophy...1994:157-167] which was relegated to the "dustbin of history" with the advent of "homo mensura" and the ensuing anthropomorphizing of the western philosophical thought.

The entrapment of the western civilisation in the ontological duality of the (anthropomorphic) spirit

\footnotetext{
6 These are legal norms established before the creation of the environmental law at the time of the "industrial revolution".

7 This expression is used by Eder, who wishes to emphasise the rationalist (Cartesian) basis of the environmental law. "When we speak of ecological reason we mean that the exploitation of nature has gone too far and that the pollution of nature must be limited. If we were to follow only this rationality, that would indeed make our exploitative interaction with nature more rational, but it would remain an exploitative way of interacting with nature" [Eder 1996:VII].

8 Kotze's starting point in his article is similar: "Law has failed to address the ever-deepening socio-ecological crisis of the Anthropocene. In the light of, and as a response to, law's failures in this respect, in his article he argues in support of developing a new legal paradigm for the Anthropocene epoch called Earth system law" [Kotzé 2019].

9 Nomos is understood as a normative social system of the western cultures, whereby the rules of behaviour are characterised by the attribute of lawhood. In the western cultures nomos is a synonym for legal rules governing behaviour. Their content depends on the context defined by the legal and political philosophy and/or the spiritual framework of a certain culture as the "ideological" superstructure of nomos.

10 The term "environmental law" connotes a set of legal norms governing man's communication with other cosmic phenomena (nature) - thus determining the rules of behaviour towards other biotic communities which, together with the norms regulating human private interaction and norms regulating social interaction, i.e., norms regulating man's social and political character, represent the "human" nomos, the "human formula" [Kaufmann 1994].

11 The issue of relationship between man and other natural entities received minimal attention within the established modern western philosophy. Within the framework of this essay it is not possible to examine in more detail certain exceptions. Of the modern philosophers "stricto sensu" we should only mention Heidegger (his philosophical ecocentrism is explored in more detail by Zimmerman in [Zimmerman 1994: 91-150]; of considerable interest is also Levi-Strauss's ecocentric "practical philosophy" [Lévi-Strauss 1992]. Nietzsche and Bergson also indirectly opposed the rationalist anthropocentrism [Zimmerman 1994:57-91].

12 The established term is "Environmental Philosophy".

13 The "secular" awareness and not the philosophical awareness "stricto sensu" is meant here, created at the time of "destruction of Nature" and encouraged by the scientific findings and traditions of other cultures.
} 
and matter which has placed man on the pedestal, at the crown of creation, and made him the master of the universe, has not been questioned, not even by Kant, who is well known ${ }^{14}$ for solving another dualist issue of the West (epistemological dichotomy between reason and experience) ${ }^{15}$.

In conjunction with the new ontology and the new ethics, the "new philosophy of nature" represents one of the key starting points for the transformation of nomos, i.e., a transformation of new legal and political philosophy and thus also new (instrumentalised) law of nature.

In view of the centrality of nomos in the western cultures, its very transformation is quintessential for the enforcement of the ecocentric social construction of nature. The transformation of nomos means the transformation of the system ${ }^{16}$ which regulates the behaviour of man at the everyday level, i.e., the normative legal system.

In terms of the "status of Nature," the current "ecologisation" of nomos ${ }^{17}$ connotes in particular the creation of obstacles and constraints of human interaction with Nature. The measure for human interaction with Nature is the maintenance of natural equilibrium.
The "resurrection" of environmental awareness in this century has triggered different approaches to the philosophical construction of nature.

The ecological situation at the turn of the 20th century ${ }^{18}$ triggered (first in the USA) the beginning of ecological anthropocentric awareness ${ }^{19}$. The criterion adopted in this approach to the issues of the "destruction of Nature" is the criterion of human health and comfort which necessitates the cleaning of the environment and a more careful exploitation of natural resources ${ }^{20}$. The philosophical framework for this approach is still Cartesian, issuing from the anthropocentric ontology and utilitarian ethics.

This (philosophical) approach represents the baseline for the dominant political and legal construction of Nature, i.e., "environmental protection"21.

At the same time, the ecological impulse spurred (again first in the USA) the creation of the ecological ecocentric awareness ${ }^{22}$, which rejects the anthropocentric construction of nature and takes into account the new scientific developments, giving rise to a new, ecocentric ontologyf and ethics. From the ontological point of view, man's place is in Nature, as an equi-valent and co-dependent part of Nature.

\footnotetext{
${ }^{14}$ When he argued that it is not possible to cognise objectivity only through the faculty of mind (on the basis of reason and senses). Reason does not cognise things "per se", as they are "in reality", but only as they "appear" through the medium of senses (experience). As reason is not able to see, only sensual and experiential objects are given, i.e., "phainomena" of objects (objectivities). Reason may not penetrate "noumena", "things in themselves", i.e., the objectivity itself. It is not capable of "penetration" (in the sense of spiritual-intellectual gaze), but is merely the faculty of thinking the object of the sensuous gaze. It is only capable of synthesising the varied, contained in the sensuous gaze, into a notion. Reason thus processes and shapes only that which is transmitted by senses, i.e., phenomena. The cognisant use of rational notions does not refer to the reality per se, but to its phenomena: the objects of possible experience. There can be no a priori knowledge except of objects of possible experience [Kaufmann 1994:85-86].

15 If we accept Kaufmann's interpretation of the connection between the dominant orientation of philosophy with the actual (ecological) circumstances of individual periods [Kaufmann 1994: 27-32], Kant was primarily concerned with epistemological issues i.e. the issues of cognition of reality, because he lived in a period of transition. The fundamental philosophical issue at a "time of doubt and mistrust" [Kaufmann 1994:28] is the following: How to arrive at the knowledge of the "external world" from my awareness? This means: How can I know anything? What is at stake here is not a thing, object, entity, but an awareness, a method. What can easily happen is what Goethe reproached Kant's philosophy at one point, namely, that it no longer arrives at the object [Kaufmann 1994:29].

16 This is the incorporation of the systemic ecocentrism in the western cultures.

17 The "ecologisation" of nomos implies the incorporation of new ontology and ethics into a legal value system.

18 The "destruction of Nature" as a result of intense development of "industrie". For "state of Nature" at the turn of the 20th century see [McCormick 1995:1-20; Ponting 1993:346-393].

${ }_{19}$ This is so-called "shallow ecology". "Shallow ecology is anthropocentric, or human-centred. It views humans as above or outside of nature, as the source of all value, and ascribes only instrumental, or "use" value to nature" [Capra 1997:7].

20 Whilst the approach of "cleaning up the environment" can not be incorporated in a philosophical context, the approach of "rational" exploitation of natural resources is connected with the "conservation philosophy," which is usually linked in literature to the name of Gifford Pinchot, a well-known forestry expert from the USA from the beginning of the 20th century.

${ }^{21}$ Environmental protection" is an approach dealing mostly with the issues of pollution, which it approaches from the point of view of anthropocentric construction of nature. It sees man as the master of nature and the issue of "destruction of nature" as merely the issue of the pollution of his environment. Such approach does not perceive the issue of the "destruction of Nature" as a deeper problem of man's un-limited interaction with all forms of Nature and not only man's environment.

22 This is so-called. "preservation philosophy," personified at the level of "practical philosophy" by John Muir and Aldo Leopold and at the level of philosophy "stricto sensu" by Henry David Thoreau and Ralph Waldo Emerson. See also [McCormick 1995:126; Natural Resources Policy 1993:162-182].
} 
This ecocentric ontology has also given rise to the ecocentric ethics which imposes on man a respectful interaction with other natural entities preserving the natural equilibrium ${ }^{23}$.

The above approach is the departure point for the further development of ecocentric philosophy of nature ${ }^{24}$. The key philosophical orientation is the philosophy of "deep ecology" [Law and the Environment....1997:91-96; The Politics...1997:61-71].

Together with the already mentioned ecocentric ontology $y^{25}$ and ethics ${ }^{26}$, one of its basic premises is the "naturalness" 27 of man's (material) interaction with other natural entities [Tarlock 1988:179-181]. However, man's centrality in Nature and man's codependence and connectedness with other natural entities demand a respect for the limitations of the natural equilibrium [Foundations...1997:39-44] ${ }^{28}$; which also connotes an enframing of the current unlimitedness of human interaction with Nature and/ or satisfaction of human (material) needs within the constraints of the natural equilibrium ${ }^{29}$.

The philosophy of "deep ecology" stems, therefore, from a redefinition of the progressiveness of human development, in particular, the orientation of the western cultures into un-limited material progress. It implies, therefore, a redefinition of the "functioning economy" of western cultures [Fredericks 2014:24].

The new "philosophy of nature" ${ }^{30}$ has been gradually gaining ground since its initial position of "counterculture" [Zimmerman 1997:91-150] and has become increasingly prominent within the established western philosophy [Philosophy... 1994:38]. It represents a philosophical departure point for a new, ecocentric paradigm [Capra 1997:6]. This discussion, however, stresses its political operationalisation, comprised in the concept of "sustainable development," which is the basis for the transformation of western cultures.

\section{The concept of "sustainable development" and the necessary formation of "systemic ecocentrism" of the western cultures (premises of ecocentric legal and political philosophy)}

The ecological situation, on the one hand, and the increasing scope of ecocentric ecological awareness, on the other hand, led to a global political agreement at the turn of the century in the form of the principle of sustainable development ${ }^{31}$.

\footnotetext{
23 "A thing is right when it tends to preserve the integrity, stability, and beauty of the biotic community. It is wrong when it tends otherwise" [Law and the Environment...1997:4]. Regarding the issue of ecocentric ethics, i.e., ethics which emanates from man's co-dependence and connectedness with other biotic communities (i.e., ecocentric ontology) and commands a respectful interaction with Nature, the question of motive of the ecocentric ethics arises. Why should I show respect for other biotic communities? The motive may be heteronomous and I show respect because I realise that I endanger myself if I continue the exploitative interaction. In this case, Nature only has instrumental value. Nevertheless, this approach represents significant progress in comparison with the anthropocentric ecological ethics. Whilst only imposing the protection of man's environment, the ecocentric ecological ethics with its heteronomous motive refers to the maintenance of the equilibrium of biotic communities, or Nature as a whole, that I show respect because other parts of Nature have intrinsic value - they are a value in themselves apart from the importance they carry for man.

${ }^{24}$ At the level of legal construction of nature this approach influenced the formation of the legal category of "nature values" national parks, first in the USA at the turn of the 20th century.

25 "Human species, along with all other species, are integral elements in a system of interdependence such that the survival of each living thing, as well as its chances of faring well or poorly, is determined not only by the physical conditions of its environment but also by its relations to other living things. (...) Humans are not inherently superior to other living things, they are members of the Earth's Community of Life in the same sense and on the same terms in which other living things are members of that Community" [Foundations...1997:29-30].

26 "Human use of the environment should not be destructive but should enhance the diversity, integrity, stability, and beauty of the biotic community. Individual plants and animals used by humans should be thoughtfully selected, skilfully and humanely dispatched and carefully used so as to neither waste or degrade them" [Earthly Goods...1996:61-62].

27 Unlike certain extreme approaches, "inspired" by Leopold's ethics and the "state of Nature" at the beginning of the 20th century, advocating the approach "let nature be nature" or striving for extreme limitations of human interaction with Nature.

${ }^{28}$ Revezs defined natural equilibrium is as the limit of human interaction with other natural entities, whereby the natural equilibrium defines the equilibrium of life of all biotic communities. Such is the prevailing approach. There are, however, more radical approaches where the ecocentric ethics claims respect for individual members of other biotic communities and also the respect for "non-life", i.e., non-living parts of Nature.

29 "Richness and diversity of kinds of living beings have intrinsic or inherent value. Humans have no right to reduce this richness and diversity except to satisfy vital human needs" [The Politics...1997:65].

30 Or the "ecosophy" (philosophy of ecological harmony). See also in Slovene philosophy [Hribar 1991:11-16].

31 Declaration of the UN Conference on Environment and Development of 12 August 1992. URL: https://www.un.org/en/ development/desa/population/migration/generalassembly/docs/globalcompact/A_CONF.151_26_Vol.I_Declaration.pdf(ac-
} cessed 12.05.2021). 
The principle of sustainable development (with its goals - i.e. Sustainable Development Goals: $\mathrm{SDG}^{32}$ ) is understood as a political operationalisation of the ecocentric ecological awareness ${ }^{33}$. It is understood, therefore, as an approach requiring humankind to adapt their interactions in conjunction with other biotic communities to the basic "law of Nature", i.e., inter-connectedness of all natural entities ${ }^{34}$. In this context, the preservation of a balanced state of $\mathrm{Na}$ ture (all biotic communities) is essential. With regard to the centrality of the (un-limited) material progress, the adjustment of the production process of material goods is therefore essential, i.e., the adjustment of economy. It should be emphasised that this is not the principle of "zero growth" ${ }^{35}$, but a principle of adjustment of material progress (development) to the constraints of natural equilibrium ${ }^{36}$. In reference to the existing excessiveness of the economic interaction with Nature [Richardson 2012:56], the current adjustment implies, of course, a limitation of the economy.

As an inter-national political agreement ${ }^{37}$, the principle of sustainable development has a twofold meaning. Firstly, it is a political and social programme of cultural transformation of human communities all over the planet. And secondly, with regard to the actual social organisation of man (national states) it must be suitably incorporated within the individual social systems, providing therefore a relevant framework for the transformation of law. When incorporating the principle of sustainable development into legal order, the pervasiveness of anthropocentrism in all segments of the western cultures needs to be taken into account ${ }^{38}$. The ontological and ethical orientation of the said principles does not have its "roots" in the existing (legal) value system and/or established western legal and political philosophy ${ }^{39}$. The western legal philosophy has not included other natural enti-

32 Sustainable Development Goals are: 1. End poverty in all its forms everywhere, 2. End hunger, achieve food security and improved nutrition, and promote sustainable agriculture. 3. Ensure healthy lives and promote well-being for all at all ages, 4. Ensure inclusive and equitable quality education and promote lifelong learning opportunities for al, 5 . Achieve gender equality and empower all women and girls, 6 . Ensure availability and sustainable management of water and sanitation for all, 7. Ensure access to affordable, reliable, sustainable and modern energy for all, 8. Promote sustained, inclusive and sustainable economic growth, full and productive employment and decent work for all, 9. Build resilient infrastructure, promote inclusive and sustainable industrialization, and foster innovation, 10. Reduce income inequality within and among countries, 11. Make cities and human settlements inclusive, safe, resilient, and sustainable, 12. Ensure sustainable consumption and production patterns, 13 . ake urgent action to combat climate change and its impacts by regulating emissions and promoting developments in renewable energy, 14. Conserve and sustainably use the oceans, seas and marine resources for sustainable development, 15. Protect, restore and promote sustainable use of terrestrial ecosystems, sustainably manage forests, combat desertification, and halt and reverse land degradation and halt biodiversity loss, 16 . Promote peaceful and inclusive societies for sustainable development, provide access to justice for all and build effective, accountable and inclusive institutions at all levels, 17. Strengthen the means of implementation and revitalize the global partnership for sustainable development. UN General Assembly: Resolution adopted by the General Assembly on 25 September 2015 "Transforming our world: the 2030 Agenda for Sustainable Development". URL: https://undocs.org/A/RES/70/1 (accessed 12.05.2021).

${ }_{33}$ Such an approach is crucial. Dick Richardson in his in-depth study of the concept of "sustainable development" calls attention to some of his anthropocentric predecessors (Brundtland Commission Report, Our Common Future). "Our Common Future not only emphasised that economic growth was still an objective of human society, but also advocated a five or even tenfold increase in world manufacturing output. It accepted the Western development paradigm and profligate Western lifestyle as a model for the industrialising world. Ecological sustainability was not seen as primary in the policy-making process, but rather as only one of a number factors" [Richardson 2012:52]. That is why the necessity of incorporation of the concept of "sustainable development" in ecocentric framework should be emphasised.

34 To achieve its goals this transformation (from Anthropocene - i.e. anthropocentrc orientation of modern society to its ecocentric orientation) is essential. Namely: anthropocentric orientation of modern society (together with the dominant belief un-limites material progress) is the main reason for ther present state of environment.

35 This was proposed by the Club of Rome [Meadows, Randers, Meadows 2004].

${ }^{36}$ The implementation of the principle of sustainable development is therefore connected with the definition of the "natural equilibrium". In Slovenian law, the natural equilibrium is defined in Article 3 of the Nature Protection Act as a state of mutually balanced relations and influences of living beings among themselves and their habitats. Under the law the natural equilibrium is upset if human activity destroys a biocenosis in terms of quantity or quality; if it encroaches on or destroys the habitats of plant or animal species or affects the proper functioning of ecosystems; if it interrupts the mutual connection between individual ecosystems or causes a significant isolation of certain populations.

37 Similarly, Correa and Venâncio argued in their article [Charting...2019: 53-54] that International Environmental Law Needs a New Paradigm, which was established as a "sustainable development principle" and and should be further developed as global pact for the environment.

${ }^{38} \mathrm{~K}$. Eder ascertains that the pervasiveness of anthropocentrism in the western cultures practically "pushes" us into the exploitation of nature. [Eder 1996: VII).

39 One of the quintessential values of the western cultures is the material progress and/or the satisfaction of material needs. This value is directly connected with the exploitative and/or anthropocentric attitude of man towards other natural entities. 
ties in the quest for the "human formula" [Kaufmann 1994:134].

From the ecocentric ontology, i.e., co-dependent position of man in "ecological community" [The Ecological Community...1997] issue the rules of behaviour, i.e., ethical norms, with the following essential commandments: show respect for other natural entities, treat them with respect and satisfy own personal (material) needs within the limits of the natural equilibrium. When other natural entities are being used (to meet own needs) the limit determined by the natural equilibrium must never be overstepped. The basic value of the nascent culture is the maintenance of the natural equilibrium; its implementation necessitates a limitation and/or adjustment of one of the key existing values - material progress and/or un-limitedness in satisfaction of material needs. The limitation is necessary because the un-limitedness of the material progress has brought about the destruction of Nature. Man must return within the boundaries set by the natural equilibrium.

The oppositeness of the above mentioned values is manifest: on the one hand, there is unlimited exploitation of nature generated by the tendency towards an un-limited material progress and, on the other hand, the need for the adjustment of the use of Nature and/or the adjustment of satisfaction of material needs to the constraints of the planet and/ or Nature, i.e., constraints defined by natural equilibrium. However, this is not the oppositeness between the value of the material progress itself and the value of the preservation of natural environment. The oppositeness relates to the un-limitedness of material progress, i.e., the un-limitedness and/or exploitativeness of human interaction with Nature.

It has to be established that despite the "breakthrough" of the issues of the relationship between man and other natural entities from the margins of philosophy ("counterculture") in the last decade ${ }^{40}$,
Nature continues to be ignored in the dominant contemporary legal philosophy and social theory (political philosophy) regardless of the ideological or philosophical origin.

Regardless of the possible reasons for such ignorance, this stance, today, when these issues have become global political issues can not be explained otherwise than by entrapment within the context of anthropocentric orientation of the western culture.

Man's "descent" into Nature implies, therefore, a value system which has "no roots" ${ }^{11}$ in the western cultures. In other words, in the actual established legal and political philosophy as the "ideological superstructure" and the starting point of the positive law and the state, the central position is taken by man and just satisfaction of man's material needs, whilst Nature (natural equilibrium) remains "outside the door".

The successful transformation of law and/or its effectiveness (influencing the change in the treatment of other parts of nature in everyday life) is therefore directly related to the incorporation of values introduced by the new awareness in a (legal) value system of the western cultures. The first step of the transformation of law is therefore the ecologisation of legal philosophy ${ }^{42}$.

\section{Discussion and Conclusion: The foundations of ecocentric legal philosophy}

Nomos is understood as the normative social system of the western cultures, whereas the rules of behaviour are characterised by the attribute of lawhood. In the western cultures, nomos is thus the synonym for legal rules governing behaviour. The content of these rules depends on the context determined by the legal and political philosophy and/or the spiritual framework of a certain culture as the "ideological" superstructure of nomos.

\footnotetext{
40 "Until recent decades, most western thinkers and traditions have been silent about the evolving rape of nature and its consequences for humanity. (...) An occasional Romantic poet, a tradition of conservationism very much outside of mainstream social and ethical theory, early (largely ignored) glimmerings in Heidegger and the Frankfurt School (...) - these exceptions prove a rule of profound intellectual blindness. Theorists for the most part took it for granted that how humanity treated the nonhuman world was not a serious problem" [The Ecological Community... 1997:X].

41 "Environmental Law is entering a critical phase because environmentalism is at a turning point. The real debate about how environmental considerations should be integrated into the economic and social order is just beginning. The next debate will be centred around the forthcoming re-evaluation of the core legislation of the environmental decade"[Natural Resources Policy... 1993:53].

42 Only a few authors have dealt with some aspects of this topic so far. In recent years Vito de Lucia in his article outlines some starting points for an ecological phidlsophy of law. See Vito de Lucia, 2013. Sara de Vdio in her artcile proposes an eco-centric approach to International Law and outlines some of ots basic principles. See: [de Vido 2021]. In this article, this topic is addressed comprehensively - in it I propose the foundations of an ecocentric legal philosophy.
} 
The nomos of the western cultures has ever since the mentioned turning point of the "homo mensura"43, i.e., the separation between humanity and nature, lost touch with the "law of Nature" (nomos theios) and has become the "property" of man - "human law" (anthropeioi nomos) [Kelley 1990:31-33; Sinha 2006:18-22]. In the history of the western civilisation, the idea of law ${ }^{44}$ has been linked only to man.

In this regard, it should be noted that this essay does not deal with the issue of lawhood (statehood) as the key attribute of "anthropeioi nomos" $"$; ; but that we are interested in the centrality of man in Nature and/or the incorporation of the "natural law" in the "human formula"46. The idea of law (justice) overlaps at this point with the issue of legal ontology. In this sense, the human formula and/or its part which regulates human behaviour in relation to other natural entities ("nomos interspecies") ${ }^{47}$ is understood as the "correct path"48 which ensures a harmonious centrality of human community in Nature.

The lawhood of the rules of behaviour is understood as a departure point ${ }^{49}$ whereby the desired deanthropocentrism of nomos needs to be redefined.
It is not possible to discuss the lawhood of the "human formula" without the state. The state is understood as a result of social agreement reflecting man's social aspect (Aristotle's zoon politikon) ${ }^{50}$.

From the point of view of redefinition of the relationship between human and other biotic communities, the incorporation of Nature in the basic social agreement or the contrat social (social agreement) is crucial and is understood as the "sample-genetic definition of civil life," as an idea of the hypothetical original state, as the widest framework for human social aspect, i.e., a frame for human community, society, in short, the "generator of civil society," whilst for the purposes of our essay, the focus lies on the entry of Nature in nomos, i.e., the (authoritative) normative system of human community.

In this sense, social agreement is understood as the contract of statehood providing the basis for the operation of the state, assigning the attribute of lawhood to the "human formula" [Contemporary Political Philosophy...2019:3-44]. The contract of statehood, therefore, is understood as the basic consensus regarding human social organisation which at the

\footnotetext{
43 In the original: metron anthropos.

${ }^{44}$ The idea of law and/or the concept of law is connected with justice. In our examination of the issue of the rules of human behaviour in relation to other natural entities, we are interested in the substantial aspects of the legal philosophy, i.e., the substantive issues of the correct, just law.

${ }_{45}$ We are not dealing with the anarchist political philosophy. Concerning law and state in the anarchist political philosophy see the excellent study by authors T. Holterman and $\mathrm{H}$. van Maarseven [Holterman, van Maarseven 1984].

46 This is Dostoyevsky's syntagm who once said: "The ant knows the formula of its abode, the bee knows the formula of its beehive - they know it not in a human way, but in their own way - but that is all they need. Only man does not know his formula" [Kaufmann 1994:134].

47 For the purpose of transparency, for that part of the human formula which specifies the rules of behaviour with regard to other biotic communities, the term "nomos interspecies" or "law of Nature" will be used and for other parts of the human formula (the rules regulating man's private interaction and the rules regulating man's social interaction, i.e., man's social and/ or political thought, the term "internal law" will be used.

${ }^{48}$ For understanding law as the "correct path" see [Fletcher 1996:38-39]. For general issues of legal ontology see [Posner 1990:161-247].

49 Here we should call your attention to the fact that the established western legal and political (liberalist) philosophies emanate from Hobbes' syntagm "homo homini lupus" and the ensuing "bellum omnium contra omnes" (hence from the assumption that man is an aggressive and selfish being) as a starting point and/or "natural state" into which subsequently enter the law and state, at the transition from a natural (pre-legal, pre-civilisation) state into a social state. This is a vulgarised interpretation of Darwin's theory, so-called social Darwinism (socio-biology), which perceives the basic "law of nature" as the food chain in which "big fish eat small fish" and applies this to the understanding of relationships among people. According to this view, conflicts among individuals and groups are resolved by competition of the parties in conflict. Such method of resolving conflicts is natural (biological), whilst resolving conflicts (contentiousness and conflictness are, as has been said before, the basic property of human community in a "natural state") through the interference of state and law is an artificial method of conflict resolution. Regardless of the already mentioned fallacy of Hobbes' assumption of the "natural state" of man, i.e., regardless of the fact that in the past there existed cultures with a different value orientation (the Iroquois, the Huron, etc.- see also Weatherford, op.cit.), the fact that the contentiousness and conflictness seems to be, in accordance with the mentioned empirical findings in the recent decades, a prevailing characteristic of the western culture. It is contentious, however, whether it is possible to expand such a finding (eurocentric) to encompass man as a species. It is contentious, therefore, whether aggressivity in relations among people in the western cultures, evident practically at every step of the way (at the empirical level as well as the level of imagination - media), allows the conclusion of man's "wolf-like" nature (biological-instinctive orientation).

${ }^{50} \mathrm{In}$ this sense we issue from the liberalist (social/political and philosophical) context of contractuality simply because of its (liberalist) all-encompassing empiricism in the contemporary western cultures. According to de-Shalit [The Ecological Community 1997:83], when discussing the transformation of nomos, it is necessary to take into account (the philosophical orientation) of the actual prevailing political context, i.e., liberalism.
} 
"material" level, the level of the positive law, is represented by the constitution, whereby we are interested in particular in that part of the contract of statehood (constitution), as a social pact, which refers to the substantive definitions, i.e., definitions of the fundamental common values and goals.

\subsection{Shaping of ecocentric legal philosophy}

\subsubsection{Premises of natural law}

The scientific realisation of man's equal position in the network of co-dependent natural entities ("prima ontologia") is certainly one of the realisations of the natural, cosmic law, the "divine nomos" ("nomos theios"), i.e., law which throughout the history of the western man has provided the criteria and norms for human behaviour.

The fundamental natural law (Logos - Heraklit), common to all natural entities, is the co-dependence and the inter-connectedness of all natural entities. The fundamental (cosmic) law is thus the same for all Nature, which means that all living beings must abide by it. It is the "cosmic formula" showing man his place in the cosmos (Nature); another issue altogether is the "human formula" and what it should be like.

In terms of rules of behaviour which man should respect in interacting with other natural entities, it is (thanks to prima ontologia) no longer possible to talk of the "indisposition" [Kaufmann 1994:50] of nature, i.e., the problem which condemned the philosophy of natural law to failure in its search for the criteria and norms for human behaviour "which would turn out to be resistant to human arbitrariness" [Kaufmann 1994:50].

"Prima ontologia" is thus cognisance obtained from Nature, allowing man to understand ${ }^{51}$ the crite- ria and norms for his behaviour towards other natural entities [Hart 1994:178]. Prima ontologia and the ensuing rules of behaviour represent the cognisance of the natural, cosmic law - order that must be taken into account in the formulation of the positive law. They are therefore the legitimisation of the correct or just law (at least in terms of the relationship with other natural entities) $)^{52}$.

"Prima ontologia" shows man his initial position- that is his (equal) postition in Nature. Man, therefore, is not merely a social, political being (zoon politikon), but is (first and foremost) a natural being (zoon physicon). The basic law of nature, the cosmic order, and the inter-interconnectedness and co-dependence of all natural entities are for the western man, defined in culture as the antipode of wild nature ${ }^{53}$, a given, committing him to action in compliance with the cosmic order.

The image of Nature as a dynamic interaction of mutually intertwined and co-dependent natural entities, signifies the restoration of the organic image of Nature ${ }^{54}$.

The above mentioned philosophical premise of law is also the basic premise of pre-Socratic philosophy (Ionic nature scientists) which was relegated to the "dustbin of history" with the advent of "homo mensura" and the ensuing anthropomorphizing of the western philosophical thought. As shown above, the centrality of western civilisation in the ontological anthropocentrism stemming from the ontological duality, was not questioned, not even by Kant in his (famous) solution of the other (epistemological) duality of the West ${ }^{55}$.

The ecocentric ontology (prima ontologia) and the ensuing ecocentric ethics has long-term consequences for the shaping of human nomos. It de-

\footnotetext{
51 This is a scientific, and thus intellectual (rational) cognisance of the "cosmic law". Kant rejected the possibility of rational cognisance of the objective world, but not entirely. He attributes to reason the potential for a priori knowledge of the objective world (not through sensuousness) within the mathematically supported natural science. Kant therefore admits the possibility of a rational cognisance of just law, if such cognisance is achieved with the aid of science [Kaufmann 1994:83-86]. See also [Brooks 1986: 36].

${ }_{52}$ Natural law has always been understood as the criterion of the positive law, as a criterion of its legitimacy. According to the classical approach, the natural law provides the basis for the positive law.

${ }^{53}$ Culture as the domain of order as an antipode to nature as the domain of disorder, chaos, stems from the already mentioned image of nature as a chaotic world which man must leave behind.

${ }^{54}$ In his discussion of the connection of natural law with the image of nature, Posner establishes the fatal consequences of the changes of the image of nature. "It was one thing to speak of natural law when nature was conceived to be the expression of divine love or order, and quite another to find universal legal norms in Darwinian nature, red in tooth and claw. The natural law project has never recovered from what Nietzsche called the death of God (at the hands of Darwin)" [Posner 1990:14].

${ }_{55}$ Although, according to Kaufmann, there was, in the field of philosophical epistemology, no way back after Kant's philosophy (epistemology), it should be emphasised that Kant was aware, even though his ontology/cosmology remains within the anthropocentric "mainstream" western philosophy (man is the master of nature), of the harmoniousness of the "starry sky above;" he saw it, however, (within the spiritual framework of his period - the liberation of man) merely as a universe of religious-artistic intuition and not as a guide for human action in relation to other natural entities. See also [Solomon, Higgins 1996:213-214].
} 
mands that man create law and social order in compliance with the mentioned premise of the "natural law". This means a departure from the western man's centrality in ontological duality which places man apart from Nature (cosmos). In creating order, the rules of behaviour, and laws, man must take into account his position in Nature (he is part of Nature and not its master) and his vital connection with other biotic communities.

If we paraphrase A. Kaufmann through the optic of ecocentrism, "law is a cluster of mutual relations of people and relations towards other natural entities" [Kaufmann 1994:32]. The mentioned (scientific) cognisance of the basic law of nature translated into the "philosophical language" means the following: the ontology of relations (among people and between man and the other parts of Nature), i.e., "prima ontologia" 56 .

If the western legal philosophy has dealt so far with the filling of the void which has occurred with the "banishment of Nature," Nature has re-surfaced as the force aided by science to guide human behaviour in relation to other natural entities.

The search for the natural law does not focus on a preordained collection of natural laws which would determine the rules of social (human) order, but merely the "cosmic order" which would show man his true place in creation, in Nature.

This is then the issue of relation between man and Nature and hence the issue of "cosmic formula". From here on it becomes the issue of the "human formula", i.e., human nomos.

The answer to the issue of what the "human formula" should be like depends on the cognisance of the "cosmic formula". The ideological and value orientation of the human law (and hence the rules regulating the relationships between people) depends on the previous ontological cognisance of the relationship of man with Nature, the remaining $\operatorname{cosmos}^{57}$.

Insofar as "prima ontologia" is based on the image of wild nature which man must cultivate to establish order, the ideological basis for human nomos also rests on the image of the man as a savage, living in a natural state "bellum omnis contra omnem". Hence the human nomos is a means of creating social order from the natural state of chaos and dis-order ${ }^{58}$.

If, on the other hand, prima ontologia is based on man's centrality in the dynamic harmonious relationship with nature, this underlying view has a corresponding value system in human nomos ${ }^{59}$. The anthropological and, therefore, empirical confirmation of the mentioned link can be found in most nonwestern ("primitive") cultures ${ }^{60}$.

If the western philosophy of law has been predominantly characterised by an awareness of a lack of knowledge about human law (and what it should be), this, according to Kaufmann [Kaufmann 1994:134], only reveals a deep insecurity as to what man really is. Or, in the words of Dostoyevsky: "The ant knows the formula of its abode, the bee knows the formula of its beehive - they know it not in a human way, but in their own way - but that is all they need. Only man does not know his formula" [Kaufmann 1994:134].

The search for man's "formula" begins in "prima ontologia", i.e., in the knowledge of the oneness of the reality whose part man is. The subjective-objective notion of reality in which man "observes" Nature

\footnotetext{
56 "Instead of the ontology of substance, ontology of relations should be developed" [Kaufmann 1994:32].

57 For more detail on the connection of human relations with Nature inside human community see [The Ecological Community....1997:2-21]. On the basis of anthropological sources, Wenz demonstrates the direct link of the "conquest" of nature, i.e., the anthropocentric social construction of nature with the wish to control, dominate, or, in the words of Derrida "controlimpulse". "Human oppression results largely from technologies and institutions developed under the guidance of mainstream anthropocentric views. (...) Devaluation of nature is related not only to the development of more advanced agriculture, increasingly complex social divisions of labour and relations of exploitation, but also to the desire for control" [The Ecological Community...1997:4]

58 Hobbes's legal and political philosophy is one of the cornerstones of the western culture. For an analysis of the western cultures from the point of view of a "mechanical" model of social community see [Merchant 1980:206-215].

59 The connection of man with other parts of Nature and man's relationship with fellow human beings was already the subject of study by Montaigne in the western philosophy. Montaigne posits that a brutal attitude towards animals leads to the brutal attitude to people. For more detail see [Kirn 1992:10-11].

${ }^{60}$ Within the framework of this essay it is not possible to give more attention to this issue. For more information on the direct relationship of individual cultures of the North American Indians with nature and human relationships (also between men and women) see [Weatherford 2010; Forbes 1992].

The underlying ecocentric value of human nomos is best illustrated by the wisdom of the chief of the Indian tribe Nez Perce: "Treat all men alike. Give them all the same law. Give them all an even chance to live and grow. All men were made by the same Great Spirit Chief. They are all brothers. The earth is the mother of all people, and all people shall have equal rights upon it" [Words of Power...1994:48].
} 
"from above" and questions his own essence does not, of course, provide the framework for solving the riddle of man's formula.

The different ontological premise of man's position in the universe, i.e., "ontology of relationships," provides assistance in the search for the "correct and just" human nomos. Only cosmic nomos exists objectively (in nature), whilst man must find his own nomos, his own "formula".

The ecocentric value orientation of nomos will thus have to be gradually reflected within that part of "human formula" which regulates the mutual interaction of human community (i.e., in the "internal law" of human community $)^{61}$. The inter-connectedness of all natural entities (human and other biotic communities), i.e., mutual ecocentric interaction, as the ontological characteristic of man's position in cosmos, is (also) the underlying value of the "internal human law"62.

\subsection{Redefinition of the western legal philoso-} phy - natural equilibrium as the underlying universal legal value (ecocentric legal philosophy)

\subsubsection{Idea of law}

The scientific realisation of man's equal position in the network of co-dependent natural entities ("prima ontologia") has re-introduced the issues of man's centrality in Nature on the stage of the western philosophy. Other natural entities "have returned" to the western philosophy of law, for centuries "burdened" merely with the issues of man.

The determination of the rules of conduct which man must respect in interaction with Nature also implies an expansion of the idea of law itself (justice and correctness). Justice also refers to the interaction between man and Nature and not only to the interaction within human community. Just law, therefore, (from the point of view of relationship between human and other biotic communities) is law which complies with the ecocentric ethics, law which directs man's conduct in order to preserve the natural equilibrium. Consequently, the economic interaction has to be maintained (kept) within the framework ensuring the vitality of other biotic communities.

"Prima ontologia" as the scientific cognisance of the dynamic link and co-dependence of all biotic communities is the philosophical premise of nomos. The connectedness and co-dependence, i.e., the ecocentric ontology, implies the exercise of respect and care in human interactions with other natural entities, and hence implies the ecocentric ecological eth$i^{6 s^{63}}$. Its essence is to keep the economic interaction within the framework ensuring the vitality of other biotic communities ${ }^{64}$.

At this point we have to address the issue of whether the obligation to respect the natural equilibrium stems from the "rights" of other (living and non-living) natural entities. And whether the prima ontologia demands an expansion of the theory of rights to other natural entities. The concept of the expansion of legal rights was developed by Christopher Stone in his well-known article Should Trees Have Standing? - Toward Legal Rights for Natural Objects [Stone 1972]. In a similar vein, Levi-Strauss argues for the proposed amendment of the Universal Declaration of Human Rights [Lévi-Strauss 1992:340-346].

Stone posits that the (scientific) cognisance of man's co-dependent centrality in Nature dictates an expansion of rights to other (living and nonliving) natural entities. In a persuasive argumentation, which he begins with a review of the historic expansion of rights (from slaves to legal persons), Stone argues for the expansion of rights. In this he follows the pragmatic orientation, i.e., the possibility to represent the interests of other biotic communities before the courts. The essence of Stone's conception is the possibility of setting up guardians to represent the rights of other biotic communities before the courts.

\footnotetext{
${ }^{61}$ Kotze similarly points out in his article that affording non-humans rights is also a way of acknowledging that law does not sufficiently cater for interspecies justice, but that it should. In fact, it is essential to appreciate that the human impact on the non-human world is also a matter of interspecies injustice [Kotzé 2019:6-7].

62 Interactiveness in the sense specified above as a characteristic of human "internal law" has been established by Unger with regard to ancient China. "All in all, the feudal world of ancient China provides us with wonderful example of society almost wholly dependent on interactional law and not yet acquainted with other sorts of law". [Unger 1997:96].

63 The motive for ecocentric ecological ethics may be heteronomous when we show respect and care in our interaction with other natural entities because we are aware of the negative consequences caused by the aggressive exploitativeness of the human community or autonomous when we show respect and care because of the natural entities themselves.

${ }^{64}$ This approach has been criticised by certain ecocentric philosophers as "speciesism" [Foundations...1997:43].
} 
Levi-Strauss's argumentation is somewhat narrower in that it proposes an expansion of rights to encompass the community of life. In recognising the rights, he aims higher, i.e., to the creation of the new Declaration of Rights. "May we then imagine such a basis for freedoms which would be self evident enough to be applicable to all without discrimination? Only one was noticed; however, it demands that man be no longer defined as a moral being, but as a living being, which is his most noticeable property. If, however, man's rights are most of all the rights of a living being, it follows directly that the natural boundaries for these rights, recognised for humankind as a species, are defined by the rights of other species. The rights of humankind terminate when their implementation endangers the existence of another species" [Lévi-Strauss 1992:342].

The system of (human) rights is one of the central elements of the social organisation of western cultures. The right is actually a materialisation of justice (a just state respects the rights; human interaction is just if rights are respected). If in our search for the answer to the question, we depart from the actual philosophical context of rights, a single conclusion is possible. Justice in relationship to others (and hence also natural entities) is only possible if they have rights.

As shown above, humankind is in a period of transition from the "environmental protection" to the "maintenance of the natural equilibrium". An essential difference between the two is that the latter demands that man respect other biotic communities. We believe that this basic position necessitates the recognition of the rights of other biotic communities [Ortolonao 1997:37-39].

Although some may disagree, it should be noted that the value systems with regard to rights have shown to be transitory in history (slaves, women), so we can expect this to be the case with regard to the rights of natural entities ${ }^{65}$.

The matter of (other) natural beings rights has been widely discussed in past years by different authors. Maria Valeria Berros in her article "Rights of Nature in the Anthropocene: Towards the Democratization of Environmental Law?" [Charting...2019:21-31] examines the processes of recogni- tion of the Rights of Nature that have taken place in recent years, emphasizing the Latin American case. She argued that this recognition can enrich sociolegal and ethical debates and thus enhance the defence of the natural world. She also argues that the Anthropocene presents a new opportunity for real and integrative collaboration among natural and social sciences and the humanities as well as the different types of knowledge and worldviews existing in our world, especially those of Indigenous Peoples. Finally, she argues that it is possible to consider a slow process of democratization of environmental law that implies several challenges for sociolegal research [Charting...2019:26-30].

Despite the seemingly impossible establishment of the rights of other biotic communities de iure, some legal acts have managed to assign these rights de facto. Ortolano cites the example of the American Endangered Species Act (ESA) protecting the animal and plant species identified as endangered and demonstrates that the lawmaker de facto recognised the rights of individual animal species by granting them protection [Ortolano 1997:38].

I believe that the definition of natural equilibrium should be considered the criterion of human interaction with other biotic communities for de facto recognition of their rights, namely the right to existence. Respect for natural equilibrium also "covers" the rights of other biotic communities to existence. The threat to natural equilibrium should be understood as endangerment of the right of other biotic communities to existence. Respect for interaction with Nature issues from the rights of other biotic communities to existence and implies the obligation to maintain the natural equilibrium ${ }^{66}$. This provides the basis for the maintenance of the natural equilibrium as a duty for man as an individual and as a duty for the state to ensure it.

A shift from the existing framework of "environmental protection" to the framework of "maintenance of the natural equilibrium" means therefore a shift from the anthropocentric approach of "environment purification" to the ecocentric approach of the maintenance of the state of equilibrium in relationships between human and other biotic communities, whereby the approach is dynamic and not static.

\footnotetext{
${ }^{65}$ We should emphasise that to recognise rights to other biotic communities would certainly not mean that their rights would be equal to the rights of the people and it would also not mean that all biotic communities would have equal rights. The criterion for the scope and the type of rights is natural equilibrium. It is not possible to examine this issue in greater detail within the framework of this essay. See also [ Stone 1988; Toulmin 1988; Tarlock 1988].

66 This, of course, is not an absolute. The duty to preserve the natural equilibrium (respect for the right of other biotic communities to existence) is limited with so-called basic (vital) needs of man.
} 
The concept implied is the concept of "dynamic equilibrium", whereby human interaction with other parts of Nature is inherent to the "dynamics of nature". The ethical imperative therefore is not the withdrawal of man from Nature but an attitude of respect in interaction ${ }^{67}$.

Tarlock in his article The Nonequilibrium Paradigm in Ecology draws attention to the importance of understanding the dynamism of natural equilibrium in the creation of the natural law. Unlike the current prevailing belief with regard to the static nature of the natural equilibrium, the transformation of the natural law must take into account the latest scientific findings with regard to the dynamic and chaotic nature of the constantly changing ecosystems. According to Tarlock, such a scientific premise dictates a turning point in the natural law. "Enhancing the capacity" of law for an ongoing monitoring of the "dynamism of nature" is essential [Law and the Environment...1997:31] $]^{68}$.

\subsubsection{Legal values}

The incorporation of Nature in the very essence of law inevitably triggers a redefinition of legal values. The natural equilibrium, i.e., the equilibrium of life (including human life), as a central value of ecocentric ecological awareness is becoming a legal value. In this sense, we could speak of the expansion of the legal subject, i.e. the expansion of values which are the subject of legal protection.

The following is of crucial importance: natural equilibrium is becoming a basic and a common legal value.
4.2.2.1. Natural equilibrium as a fundamental (basic) legal value

The definition of natural equilibrium as a criterion (framework) of correct law places the maintenance of natural equilibrium as a legal value in initial position. It is obvious that the natural equilibrium is thus becoming a fundamental legal value, a fundamental criterion of the correctness (justice) of law.

The initial position of natural equilibrium means that the constraint of natural equilibrium defines in particular the human interaction which has the function of satisfaction of (material) needs, i.e., economic interaction. The initial position of the maintenance of natural equilibrium as a legal value implies the enframing of the other (legal) value, i.e., the satisfaction of material needs (economic interaction).

In his satisfaction of (material) needs, man is no longer un-limited ${ }^{69}$, but is constrained by the framework defined by the natural equilibrium.

A redefinition of legal philosophy directly limits the exploitativeness (un-limitedness) of the satisfaction of human material needs (but does not limit the satisfaction of material needs as such) and/or redefines the orientation of the western cultures towards an un-limited material progress ${ }^{70}$, which means that man has returned within the boundaries set by the natural equilibrium. The initial position of the maintenance of natural equilibrium thus does not mean the "sacrifice" of economic progress ${ }^{71}$, but implies its enframing within the boundaries of the natural equilibrium.

\footnotetext{
${ }^{67}$ Such ethical approach could be expressed also with the paraphrase of the well-known Leopold's maxim: "A thing is right when it tends to preserve the dynamic (added by P.S.) integrity, stability, and beauty of the biotic community. It is wrong when it tends otherwise" [Foundations...1997:41].

68 "The major institutional change necessitated by the nonequilibrium paradigm is the need to apply adaptive management to biodiversity protection. (...) We favor management consistent with the core idea of the rule of law - consistent application of fixed rules to yield a single, final decision. Our environmental laws accept a scientific premise and then requires its continued application regardless of subsequent research findings and thinking. (...) Adaptive management, in contrast, is premised on the assumption that management strategies should change in response to new scientific information" [Law and the Environment ...1997:31].

69 The un-limitedness of the (economic) interaction with Nature is linked with the conviction of the western cultures that the (material) development also is un-limited. This conviction, however, rests (implicitly) on the belief in the progressiveness of human (planetary) history, i.e. constant progress - the transition from worse to better [The Ecological Community 1997:362]. 70 Similarly [Law and the Environment...1997:420].

71 To assume that the conflictness of the maintenance of natural equilibrium and material progress is insurmountable is a fallacy. In the conflict involving the maintenance of the natural equilibrium, the un-limitedness of the material progress exists insofar as it is linked with the un-limited burdening of Nature, and thus the exploitation of Nature. The principle of sustainable development rejects the concept of zero growth (Club of Rome) and/or "zero sum mentality". Without having to discuss man's inherent developmentality we can establish that it is not problematic per se, but that the un-limitedness of the (material) development is problematic. The basic premise should therefore be the orientation towards the material progress with its enframing as the key. The key issue is how to achieve the enframing. In our view, for the existing state (destruction of Nature) and for the "dynamism of nature," state interference in the private sphere (in particular the economy) is crucial. It is premised on the assumption of the impotence of the western economy (market), and thus its incapacity to itself provide the necessary enframing. The reason for this should be sought in its inherent orientation towards the maximisation of material progress.
} 
4.2.2.2. Natural equilibrium as a common legal value

The maintenance of the natural equilibrium is also a value in the common, public interest of human community $^{72}$. This does not relate to what we want as individuals, but to what we are as a human community [Foundations... 1997:22]. The collectivity, commonality of natural equilibrium as a legal value is the foundation for the creation of the ecocentric social theory (political philosophy). The definition of natural equilibrium as a basic and common legal value implies that the maintenance of natural equilibrium is defined as the fundamental public interest.

The "initial position" and "commonality" of the natural equilibrium assign the state the role of the guardian of the interests of human community as well as the interests (rights) of other biotic communities. They thus represent the legitimisation of state activities affecting the environment in the private sphere [Lévi-Strauss 1985:391] and thus provide the baseline for a redefinition of the political philosophy of the western cultures.

\subsubsection{Maintenance of natural equilibrium as a human right}

The investiture of the natural equilibrium in the system of legal values also gives rise to the necessity of the definition of the maintenance of the natural equilibrium as human right [Sax 1990]. Considering the necessity of the establishment of the active role of the state in the maintenance of the natural equilibrium, the state should ensure also this right. In our opinion, the environmental right should also comprise the right to the maintenance of the natural equilibrium as a traditional human right, and the guardianship of other biotic communities, i.e., the possibility of "civic" interference also in the interest of other biotic communities [Stone 1972] ${ }^{73}$. Stone's concept of legal guardianship of the interests of other biotic communities has led (first) in the American law (and later elsewhere), also on the basis of the well-known separate opinion by the Supreme Court Judge William O. Douglas in the case Sierra Club v. Morton [Schoenbaum, Rosenberg 1991:23-25] first towards the liberalisation of the "standing doctrine" 74 and later towards the creation of the statutory instrument of "legal guardianship" by so-called class-action $^{75}$.

\subsubsection{Relationship between the new legal val- ue and the existing legal values}

The initial position of the natural equilibrium ${ }^{76}$ addresses the issue of relationship of the new legal value towards the existing fundamental legal values of the western cultures. At issue is in particular the question of conflict between the new legal value, i.e., the maintenance of natural equilibrium and other legal values firmly implanted in these cultures.

The conflicting character of the "emerging" value becomes obvious at the moment when its incorporation in the legal order demands an adjustment (limitation) of certain "deep-in-structure" values of the western cultures (nomos). At issue is in particular the un-limitedness of the economic ${ }^{77}$ interaction of human and other biotic communities and the related material progress as one of the basic (legal) values of the western cultures.

The enforcement of the maintenance of natural equilibrium may also demand a limitation of another legally protected value, for example, the right to the freedom of movement or some other human right. Thus, for example, the administrative court of the state Baden Württemberg in its review of the regulation prohibiting night diving in the lake because of its negative impact on water organisms rejected the complaint by a plaintiff who claimed that this represented an inadmissible interference with the constitutional (human) right to personal development

\footnotetext{
72 In his classical study, Sagoff sees the difference between the common, public interest (common value) and the private interests (values) of individuals with regard to relation to Nature as the difference between the interests of man as a consumer and the interests of man as a citizen [Foundations...1997:18].

73 This is based on the "guardianship concept" developed by Christopher Stone [Stone 1972].

74 The courts increasingly allowed the filing of complaints with regard to the protection of the interests of other biotic communities. See also [Ortolano 1997: 43-44].

75 See also [Schoenbaum, Rosenberg 1991:28:33; Ortolano 1997: 43-44]. In the Slovene law, the provision with regard to such complaints is contained in Article 15 of the Environmental Protection Act.

76 The definition of natural equilibrium as a basic common legal value opens up the issue of the role of science as a source of the knowledge of the limits of the natural equilibrium (For more detail see Sagoff, 1988. The issue of reliability of scientific knowledge and the possible "technocratic approach" of the western cultures is thereby raised [Law and the Environment... 1997:29-31].

77 The "economic" interaction implies human activity in Nature for the purpose of production of material goods (for personal needs or for the purpose of marketing).
} 
(paragraph 1 of Article 2 of the German constitution). The administrative court estimated that the public interest (of the maintenance of "well being" of water organisms) justifies the said limitation ${ }^{78}$.

The following two values are at "conflict" here: natural equilibrium and material progress. The definition of the maintenance of the natural equilibrium as the fundamental, shared value legitimises an interference (limitation) with regard to other legal values, in particular the un-limitedness of the economic interaction. Such an intervention often represents the limitation of other legal values, also of private property $^{79}$.

The initial position of natural equilibrium is not absolute; it is limited with the vital needs of human community [Foundations... 1997:29-44; Stone 1988:1-13]. Nevertheless, each time an activity affecting Nature takes place for the purpose of meeting man's vital needs, the limits of the natural equilibrium must be taken into account as much as possible ${ }^{80}$.

The new value, i.e., the maintenance of natural equilibrium, must be incorporated in the "contracts of statehood", that is in the constitutions of the western countries as one of main legal values, next to "freedom", "democracy") and "private property" [Environmental Planning...1996:4f]. The entry of Nature in the western (legal) value system is, as I have shown, conditio sine qua non for an efficient change in the legal order and, in, most importantly, for a change in man's attitude towards Nature in eneryday?s life $^{81}$.

\section{Conclusion}

In the past decades the awareness of the necessity to "legislate temperance" in human (economic) interaction with Nature has been heightened. At the same time, it is becoming increasingly evident, that the inefficiency and "impotence" of the normative reaction to the "destruction of Nature" i.e., the development of the environmental law in the second half of the 20th century is clocely connetcted to dominant anthropocentric cultural paradigm of the western cultures, oriented towards an un-limited material progress in the age of Antrhopocene.

The scientific realisation of man's equality in the network of co-dependent natural entities in the last decades shows man his initial position - that is his (equal) postition in Nature. Man, therefore, is not merely a social, political being (zoon politikon), but is (first and foremost) a natural being (zoon physicon). The basic law of nature, the cosmic order, and the inter-interconnectedness and co-dependence of all natural entities are for the western man, defined in culture as the antipode of wild nature, a given, committing him to action in compliance with the cosmic order.

I've shown in this article that the determination of the rules of conduct which man must respect in interaction with Nature implies an expansion of the idea of law itself (justice and correctness). Justice also refers to the interaction between man and Nature and not only to the interaction within human community. Just law, therefore, (from the point of view of relationship between human and other biotic communities) is law which complies with the ecocentric ethics, law which directs man's conduct in order to preserve the natural equilibrium. Consequently, the economic interaction has to be maintained (kept) within the framework ensuring the vitality of other biotic communities.

Also, in this artcile I've shown that the incorporation of Nature in the very essence of law inevitably triggers a redefinition of legal values. The natural equilibrium, i.e., the equilibrium of life (including

\footnotetext{
78 Verwaltungsgerichtshof Baden-Württemberg:Urteil vom 22.06.1987. URL: https://www.saarheim.de/Entscheidungen/ VGH\%20Mannheim\%20-\%201\%20S\%201699aus86.htm (accessed 12.05.2021).

79 This concerns the restriction of the freedom of ownership (ecological function of property) and also direct divestment - expropriation of private property. The incorporation of the natural equilibrium as a basic common legal value in the legal value system (the Constitution), and therefore the definition of the maintenance of the natural equilibrium as the fundamental public interest, is, in our opinion, a circumstance which the citizens (owners) are expected to count on. This means that the weight of public interest is a priori very high, which has to be taken into consideration by the Constitutional Court when weighing both values, i.e., private property and natural equilibrium (principle of proportionality).

80 This is the so-called "principle of minimum wrong" [Foundations... 1997:36].

${ }^{81}$ In my opinion, the already adopted international acts which provide the grounds for the principle of sustainable development (Rio Declaration and several conventions) necessitate the amendment and/or change of constitutional acts of individual countries. Of key importance is the incorporation of the ecocentric legal philosophy (and hence the incorporation of the natural equilibrium in a system of legal values as a priority) as well as the incorporation of the ecocentric political philosophy (and thus the definition of the state as a guardian of its natural equilibrium). Certainly the inclusion of the above-mentioned international legal acts in the legal order of the individual country, even without a corresponding amendment of the constitutional act itself, requires that the existing constitutional provisions be interpreted in accordance with the principle of sustainable development.
} 
human life), as a central value of ecocentric ecological awareness is becoming a legal value. In this sense, we could speak of the expansion of the legal subject, i.e. the expansion of values which are the subject of legal protection.

In this context it is of crucial importance taht natural equilibrium is becoming a basic and a common legal value. The definition of natural equilibrium as a criterion of correct law places the maintenance of natural equilibrium as a legal value in initial position: natural equilibrium is thus becoming a fundamental legal value, a fundamental criterion of the correctness (justice) of law.

It is shown in this article that the maintenance of the natural equilibrium is also a value in the common, public interest of human community. This does not relate to what we want as individuals, but to what we are as a human community. The collectivity, commonality of natural equilibrium as a legal value is the foundation for the creation of the ecocentric social theory (political philosophy). The definition of natural equilibrium as a basic and common legal value implies that the maintenance of natural equilibrium is defined as the fundamental public interest.

It is also shown in this article tha the "initial position" and "commonality" of the natural equilibrium assign the state the role of the guardian of the interests of human community as well as the interests (rights) of other biotic communities. They thus represent the legitimisation of state activities affecting the environment in the private sphere and thus

\section{References}

1. Brooks R. Coercion to Environmental Virtue: Can and Should Law Mandate Environmentally Sensitive Lifestyles?. - The American Journal of Jurisprudence. 1986. Vol. 31. Issue 1. P. 21-54. DOI: https://doi.org/10.1093/ ajj/31.1.21

2. Buck S. Understanding Environmental Law and Administration. Washington, D.C.: Island Press. 1996. 225 p.

3. Capra F. The Web of Life. A New Scientific Understanding of Living Systems. New York: Anchor Books. 1997. 368 p.

4. Charting Environmental Law Futures in the Anthropocene. Ed. by M. Lim. Singapore: Springer. 2019. 245 p. DOI: https://doi.org/10.1007/978-981-13-9065-4

5. Contemporary Political Philosophy: An Anthology. Ed. by R. Goodin and Ph. Pettit. 3rd ed. Oxford: Wiley and Blackweel. 2019. 736 p.

6. Dryzek J. The Politics of the Earth: Environmental Discourses. Oxford ; New York:Oxford University Press. 1997. 220 p.

7. Earthly Goods: Environmental Change and Social Justice. Ed. by O. Hampson and J. Reppy. Ithaca; London: Cornell University Press. 1996. 272 p.

8. Eder K. The Social Construction of Nature (A Sociology of provide the baseline for a redefinition of the political philosophy of the western cultures.

Also shown in this article is that the initial position of the natural equilibrium addresses the issue of relationship of the new legal value towards the existing fundamental legal values of the western cultures. At issue is in particular the question of conflict between the new legal value, i.e., the maintenance of natural equilibrium and other legal values firmly implanted in these cultures.

The conflicting character of the "emerging" value becomes obvious at the moment when its incorporation in the legal order demands an adjustment (limitation) of certain "deep-in-structure" values of the western cultures (nomos). At issue is in particular the un-limitedness of the economic interaction of human and other biotic communities and the related material progress as one of the basic (legal) values of the western cultures.

The enforcement of the maintenance of natural equilibrium may also demand a limitation of another legally protected value, for example, the right to the freedom of movement or some other human right.

The new value, i.e., the maintenance of natural equilibrium, must be incorporated in the "contracts of statehood", that is in the constitutions of the western countries as one of main legal values, next to freedom, democracy and private property. The entry of Nature in the western (legal) value system is, as I have shown, conditio sine qua non for an efficient change in the legal order and, in, most importantly, for a change in man's attitude towards Nature in eneryday's life.

Ecological Enlightenment). London: SAGE Publications. 1996. 256 p.

9. Environmental Planning and Sustainability. Ed. by S. Buckingham-Hatfield and B. Evans. Chicester: John Wiley \& Sons. 1996. 208 p.

10. Fletcher G.P. Basic Concepts of Legal Thought. New York; Oxford: Oxford University Press. 1996.226 p.

11. Forbes J. Columbus and Other Cannibals: The Wetiko Disease of Exploitation, Imperialism and Terorism. New York: Autonomedia. 1992. $160 \mathrm{p}$.

12. Foundations of Environmental Law and Policy. Ed. by R. Revesz. New York: Foundation Press. 1997. 375 p.

13. Fredericks S. Ethics in Agenda 21. - Ethics, Policy and Environment. 2014. Vol. 17. Issue 3. P. 324-338. DOI: 10.1080/21550085.2014.955312

14. Hardin G. The Tragedy of the Commons. - Science. 1968. Vol. 162. No. 3859. P. 1243-1248.

15. Hart H.L.A. The Concept of Law (Slov. ed.: Hart H.L.A. Koncept prava. Ljubljana: Študentska organizacija Univerze v Ljubljani Publ. 268 p.)

16. Holterman T., van Maarseven H. Law and Anarchism. Montreal: Black Rose Books. 1984. 215 p.

17. Hribar T. Ekologija in ekozofija [Ecology and ecosophy]. - 
Glasnik slovenske Matice. 1991. No. 1-2. P. 11-16. (In Slovenian)

18. Johnston R. J. Nature, State and Economy. A Political Economy of the Environment. New York: John Wiley\&Sons.1996. $274 \mathrm{p}$.

19. Kaufmann A. Uvod v filozofijo prava [Introduction to Philosophy of Law]. založba, Ljubljana: Cankarjeva. 1994. 281 p. (In Slovenian)

20. Kelley D.R. The Human Measure. Soacial Thought in the Western Legal Tradition. Cambridge, Mass.: Harvard University Press. 1990. 358 p.

21. Kirn A. Ekološka (okoljska) etika [Environmental Ethics]. Maribor: Aram. 1992. 43 p. (In Slovenian)

22. Kotzé L. Earth System Law for the Anthropocene. - Sustainability. 2019. Vol. 11. No. 23. P.1-13. DOI: https://doi. org/10.3390/su11236796.

23. Kuhn Th. The Structure of Scientific Revolutions. Chicago: University of Chicago Press. 1962. 172 p.

24. Law and the Environment: A Multidisciplinary Reader. Ed. by R. Percival and D. Alevizatos. Philadelphia: Temple University Press. 1997. $464 \mathrm{p}$.

25. Lévi-Strauss Cl. The View from Afar. Chicago: University of Chicago Press. 1992. 311 p.

26. Lucia V. de. Towards an Ecological Philosophy of Law: A Comparative Discussion. - Journal of Human Rights and the Environment. 2013. Vol. 4. Issue 2. P. 167-190. DOI: 10.4337/jhre.2013.02.03

27. McCormick J. The Global Environmental Movement. $2^{\text {nd }}$ ed. Chichester: John Wiley \& Sons. 1995. 312 p.

28. Meadows D.H., Randers J., Meadows D.L. Limits to Growth: 30-year update. The USA: Chelsea Green Publishing Company. 2004. $338 \mathrm{p}$.

29. Merchant C. The Death of Nature. Women, Ecology and the Scientific Revolution. San Francisco: Harper and Row. 1980. $348 \mathrm{p}$.

30. Natural Resources Policy and Law: Trends and Directions. Ed. by L. MacDonnell and S. Bates. Washington, D.C. :Island Press. 1993. $241 \mathrm{p}$.

31. Ortolano L. Environmental Regulation and Impact Assessment. New York: John Wiley \& Sons. 1997.620 p.

32. Palmer D. Looking at Philosophy: The Unbearable Heaviness of Philosophy Made Lighter. Mountain View: Mayfield Publishing Company. 1994. $412 \mathrm{p}$.

33. Philosophy and the Natural Environment. Ed. by R. Attfield and A. Belsey. Cambridge University Press, Cambridge: Cambridge University Press. 1994. 250 p.
34. Ponting $\mathrm{Cl}$. A Green History of the World.The Environment and the Collapse of Great Civilizations. New York: Penguin Books. 1993.430 p.

35. Posner R. The Problems of Jurisprudence. Cambridge Mass.: Harvard University Press. 1990. 485 p.

36. Przeworski A. Sustainable Democracy. Cambridge: Cambridge University Press. 1995. $156 \mathrm{p}$.

37. Sagoff M. Ethics, Ecology, and the Environment: Integrating Science and Law. - Tennessee Law Review. 1988. Vol. 56. P. 77-229.

38. Sax L. J. The Search for Environmental Rights. - Journal of Land Use and Environmental Law. 1990. Vol. 6. No.1. P. 93105.

39. Schoenbaum T., Rosenberg R. Environmental Policy Law: Problems, Cases, and Readings. 2nd ed. Westbury: Foundation Press. $1273 \mathrm{p}$.

40. Sinha S. Jursiprudence (Legal Philosophy) in a Nutshell. St. Paul: West Academic Publishing. 2006. 379 p.

41. Solomon R., Higgins K. A Short History of Philosophy. New York; Oxford: Oxford University Press. 1996. 352 p.

42. Stone Chr. The Environment in Moral Thought. - Tennessee Law Review. 1988. Vol. 56. P. 1-13.

43. Stone D. Chr. Should Trees Have Standing? - Toward Legal Rights For Natural Objects. - Southern California Law Review. 1972. Vol. 45. P. 450-501.

44. Tarlock D. Earth and Other Ethics: The Institutional Issues. - Tennessee Law Review. 1988. Vol. 56. P. 43-77.

45. The Ecological Community. Ed.by R. Gottlieb. New York: Routledge. $1997.406 \mathrm{p}$.

46. The Politics of Sustainable Development: Theory, Policy, and Practice within the European Union. Ed. by S. Baker [et al.]. London: Routledge. 1997. 292 p.

47. Toulmin St. The Case for Cosmic Prudence. - Tennessee Law Review. 1988. Vol. 56. P.29-43.

48. Vido S. de. Quest for an Eco-centric Approach to International Law: the COVID-19 Pandemic as Game Changer. Jus Cogens. 2021. Vol. 3. Issue 2. P. 105-117. DOI: https:// doi.org/10.1007/s42439-020-00031-0

49. Weatherford J. Indian Givers: How Native Americans Transformed the World. New York: Three Rivers Press. 2010. $368 \mathrm{p}$.

50. Words of Power:Voices from Indidan America. Ed. by N. Hill, Jr. Golden, CO: Fulcrum Publishing. 1994. 64 p.

51. Zimmerman M. Contesting Earth's Future. Radical Ecology and Postmodernity. Berkeley: University of California Press. 1997. 447 p. DOI: https://doi.org/10.1525/9780520919228

\section{About the Author}

\section{Senko Plicanic,}

Associate Professor, Faculty of Law, University of Ljubljana

2, Poljanski nasip, Ljubljana, Slovenia, Si-1000

senko.plicanic@pf.uni-lj.si

ORCID: 0000-0002-0386-3595

\section{Информация об авторе}

\section{Сенко Пличанич}

доцент, Факультет права, Университет Любляны

Si-1000, Словения, Любляна, Полянская насыпь, д. 2

senko.plicanic@pf.uni-lj.si

ORCID: 0000-0002-0386-3595 